UDC 631.147

Original research paper

doi: 10.5937/AASer1846125G

Acta Agriculturae Serbica, Vol. XXIII, 46 (2018); 125-140

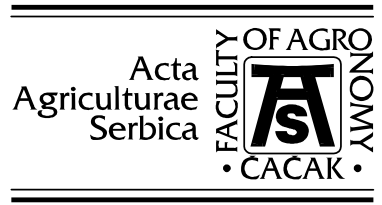

\title{
Global organic food market
}

\author{
Jelena Golijan $^{1^{*}}$, Bojan Dimitrijević ${ }^{1}$ \\ ${ }^{1}$ Faculty of Agriculture, University of Belgrade, Belgrade-Zemun, Serbia \\ *Corresponding author: helena.ilios@gmail.com
}

\begin{abstract}
Organic agricultural production enables the production of controlled, certified, safe, and high-quality food, and at the same time it provides high economic and ecological profit and preserves a healthy environment. Consumer interests in products of organic origin have been steadily growing for twenty years. The aim of this paper is to give an overview of the situation in the global organic food market, as well as to point out the most important motives for consumers to decide on the consumption of organically produced foods. All countries around the world record a trend of continual organic food and beverage market growth. In some countries this growth is expressed with doubledigit numbers. The United States is the largest organic food market, with a total of 35.8 trillion euros. Fruits, vegetables, bread, cereals, drinks, milk and meat have the biggest share in the organic food market in all countries of the world. Fresh fruits take the first position in international trade. Although the production and sale of organic food is concentrated in highly developed countries, less developed countries are becoming important producers and exporters of organic products.
\end{abstract}

Keywords: products, motives, producers, market.

\section{Introduction}

The methods of conventional agriculture that have been used for decades have led to pollution of soil and water. The misuse or overuse of pesticides and various synthetic chemical substances damages not only the environment and biodiversity (Popović et al., 2016), but also human health. This fact indicates that the production methods applied so far must be modified to achieve the sustainability of agricultural systems and enable the production of sufficient 
quantities of food in the future (Subić et al., 2010). "Organic agriculture is a holistic production management system which promotes and enhances agroecosystem health, including biodiversity, biological cycles and soil biological activity. It emphasizes the use of management practices in preference to the use of off-farm inputs, taking into account that regional conditions require locally adapted systems" (FAO/WHO Codex Alimentarius Commission, 1999). Organic agriculture is a sustainable integral ecological system for the production of safe, quality, certified foods, and at the same time it is strictly controlled in order to meet the wishes and needs of consumers, while achieving economic and ecological profits and preserving the environment (Babović, 2008). Organic products are high quality products and are safer for people's health and their environment. They have many advantages over conventional products: high nutritional value (higher contents of vitamins, minerals, essential fatty acids, proteins, etc.); high biological quality; high technological quality (when stored they maintain their quality for a longer period of time, they are more suitable for processing and distribution, they require less energy to be processed); a high content of dry matter (on average, fresh products have a $25 \%$ higher content of dry matter); high quality organoleptic properties (more intense color, taste and fragrance characteristic of the product); a low nitrate content; do not contain residues of pesticides, heavy metals, hormones, veterinary preparations, etc. (Babović et al., 2012; Tasić, 2015; Golijan and Veličković, 2015).

Thanks to the knowledge about human health risks and the need for environmental protection, organic production shows an increasing trend of growth. Organic agriculture protects the natural environment and is a prospective activity in the economy, as it contributes to the optimal use of resources, the development of rural areas and villages, sustainable exports, economic growth, and the increase in living standards (Lazić, 2010). The market and the demand for organic products are constantly increasing, and the areas under this production are increasing from day to day (Golijan and Popović, 2016). As the result of the effects of different market and legal factors in different countries, there are differences in organic food consumption both among countries and among regions. Institutional interventions in the form of creating a legal basis for the production and marketing of organic food, various forms of direct and indirect subsidies, independent control, certification and labeling, played a key role in the creation and development of the organic food market (Vehapi, 2014).

\section{Organic food}

Each producer and processor of organic products must be familiar with supply, demand, assortment of production and processing, distribution and methods of promotion of products. Since the organic form of food production is fully legally regulated, such products in the Serbian market are certified and labeled as an "organic product". The unified logo is an identity mark to 
distinguish organic products from non-organic ones, and it implies the continuity of the quality of products originating from organic production. Processed products, originating from organic production, account for a third of total production (Tasić, 2015). Organic products are available for customers in hypermarkets, health food stores, direct sales, online stores, and catering facilities. The prices of organic products in Serbia are higher than conventional ones by 30\% (Vehapi, 2015). They can be sold wholesale and to processing companies. Only $20 \%$ of farmers sell their organic products through direct sales in green markets and in retail stores (Tasić, 2015). Earlier research results in Serbia indicated that the highest percentage of consumers (36\%) was willing to pay up to $20 \%$ higher prices for the purchase of organic products than the same products of conventional origin, while only $2 \%$ were willing to pay $50 \%$ more (Vlahović et al., 2010). The main reasons for the high consumer's "sensitivity“ to price of organic products are the low standard of living and the fact that customers are not sufficiently informed about the correctness, significance, safety and quality of organic products (Golijan, 2016). Vehapi (2015) states that 89.1\% of consumers are willing to pay a higher price for organic food products compared to identical products of conventional origin (despite significantly lower personal incomes compared to the same in the EU). Also, 63\% of customers are willing to pay up to $20 \%$ higher price, $30.9 \%$ of customers would pay $25-50 \%$ higher price, while only $3.6 \%$ of those who would pay $80-100 \%$ higher prices for the purchase of organic foods than the same products of conventional origin, which confirms the fact that demand for organic food in Serbia is price-elastic (Vlahović et al., 2010; Vehapi 2014; Golijan, 2016). However, according to Thompson (1998), there are also significant differences in behavior across stores: "Organic and conventional price differences were statistically significant in explaining the choice of organic produce at a natural foods supermarket but not at a cooperative."

In countries around the world, where the organic food market is well developed, consumers show different motives for purchasing these products. However, what connects them all is the motive of preserving one's own health, which occupies the primary place (Hutchins and Greenhalgh, 1997; Schifferstein and Oude Ophuis, 1998; Squires et al., 2001; Chinnici et al., 2002; Makatouni, 2002; Conner, 2004; Padel and Foster, 2005; Zander et al., 2011; Marques Vieira et al., 2013), as consumers consider organic products healthier and more nutritious compared to conventional foodstuffs (Golijan and Veličković, 2015, Golijan et al., 2017a, 2017b, 2017c), and are therefore safer for consumption (Codron et al., 2006; Padel and Midmore, 2005; De Magistris and Gracia, 2008; Brčić-Stipčević and Petljak, 2011). In Serbia, according to Vehapi (2015), the most frequently used motives in second and third place are quality (25.9\%) and safety (23\%), respectively. Miller and Spoolman (2008) state that organic food protects the health of the manufacturer as well, while Aertsens et al. (2011) indicate that one of the main motives for the consumption of organic food is the 
absence of chemicals, pesticides and other pollutants, which is related to the motive of protecting one's own health (Ekelund, 1990; Soil Association 2012). The most frequently cited motive for the purchase of organic food in numerous studies is the contribution to environmental conservation (Von Alvensleben, 1998; Torjusen et al., 1999, Aguirre 2001, Aertsens et al., 2011; Marques Vieira et al., 2013; Pearson et al., 2013).

There are numerous barriers in the purchase of organic products in the region of European countries. According to the research conducted by Padel and Midmore (2005), respondents consider local produce not to be near-organic, or only important in a rural rather than in an urban context, barriers stemming from a food culture restricted to urban areas, and more frequent access for rural consumers to home grown vegetables (Table 1).

Table 1. Barriers to the purchase of organic foods in rural areas $(n=128$, percent of respondents)

\begin{tabular}{|c|c|c|c|}
\hline & Important $^{\mathrm{a}}$ & $\begin{array}{c}\text { Not } \\
\text { important }\end{array}$ & Don’t know \\
\hline $\begin{array}{l}\text { "Local" is more important than } \\
\text { "organic" }\end{array}$ & 80 & 18 & 2 \\
\hline Grow vegetables in their own gardens & 71 & 28 & 1 \\
\hline $\begin{array}{l}\text { Lifestyle food culture is restricted to } \\
\text { urban }\end{array}$ & 66 & 25 & 9 \\
\hline $\begin{array}{l}\text { Reduced availability of organic } \\
\text { products }\end{array}$ & 64 & 35 & 1 \\
\hline Solidarity with conventional farmers & 59 & 39 & 2 \\
\hline $\begin{array}{l}\text { Lower disposable incomes in rural } \\
\text { areas }\end{array}$ & 58 & 41 & 2 \\
\hline $\begin{array}{l}\text { Less concerned about the animal } \\
\text { welfare }\end{array}$ & 35 & 60 & 5 \\
\hline Less concerned about the environment & 35 & 60 & 5 \\
\hline $\begin{array}{c}\text { Consumers in rural area less health } \\
\text { conscious }\end{array}$ & 30 & 60 & 9 \\
\hline
\end{tabular}

Notes: " "Very important” and "important"; " "Not important" and "not at all important"

Source: Padel and Midmore (2005)

Rural consumers are less concerned about the environment, animal welfare and their own health. In emerging market countries, such as Finland, France, Italy, The Netherlands, Norway, Portugal and Sweden, respondents state that 
restriction of food culture to urban areas is a more important barrier, while in countries such as Belgium, Czech Republic, Greece, Ireland, Slovenia andSpain respondents considered home grown vegetables and lower disposable income to be more important barriers, but local food as less important.

\section{Organic Food Market in the World}

In the last 15 years, the market for organic products has increased fourfold. Organic food sales in 2015 at global level had a value of 81.6 billion US \$ (an increase of 10\%) (Table 2), with the largest growth in the North American market, which accounts for more than half the value of international sales of these foods. In 2012, organic food sales in the entire Europe had a value of 22.8 billion euros and in North America 24.1 billion euros (Scaack et al., 2014). Organic food production is performed by 2.4 million producers in 179 countries around the world. However, most of the sales take place in Europe and North America (around 90\%). In terms of regional distribution, North America is the largest market, with a value of 39.5 billion euros, followed by Europe (29.8 billion euros) and, Asia, ranking third with a value of 6.2 billion euros. Countries with the largest organic food market are the United States, with a total of 35.8 billion euros, followed by Germany with 8.6 billion euros, France (5.5 billion euros) and China (4.7 billion euros) (FiBL, 2017).

The leading market segments of organic products on the world market are: fruits and vegetables, bread and cereals, beverages, milk and meat (Figure 1). At global level, organic grain production has a continuous growth trend, reaching an area of 3.3 million hectares. The largest organic grain production takes place on the European continent, where the dominant types of grain are: wheat, corn, rice, barley, oats, rye, sorghum, millet, triticale and buckwheat. World leaders in the production of organic grain are China and the United States (Popović et al., 2017). In 2014, wheat had the biggest share in the markets of Lithuania and Romania (61.8\% and 55.7\% respectively) (faostat.fao.org). Of 11.6 million hectares under organic crops throughout Europe, grains are the most important crops with a share of 1.9 million ha (Lernoud and Willer, 2016). 
Table 2. Organic Agriculture: Key Indicators and Top Countries

\begin{tabular}{|c|c|c|}
\hline Indicator & World & Top countries \\
\hline $\begin{array}{c}\text { Countries with } \\
\text { organic acitivies }{ }^{1}\end{array}$ & 2015: 179 countries & $\begin{array}{l}\text { New countries: Brunei Darussalam, } \\
\text { Cape Verde, Hong Kong, Kuwait, } \\
\text { Monaco, Sierra Leone and Somalia }\end{array}$ \\
\hline $\begin{array}{c}\text { Organic } \\
\text { agricultural land }\end{array}$ & $\begin{array}{l}\text { 2015: } 50.9 \text { million ha } \\
\text { (1999: } 11 \text { million ha) }\end{array}$ & $\begin{array}{l}\text { Australia (22.7 million ha) } \\
\text { Argentina (3.1 million ha) } \\
\text { United States ( } 2 \text { million ha) }\end{array}$ \\
\hline $\begin{array}{c}\begin{array}{c}\text { Organic share of } \\
\text { total } \\
\text { agricultural land }\end{array} \\
\end{array}$ & 2015: $1.1 \%$ & $\begin{array}{c}\text { Liechtenstein (30.2\%) } \\
\text { Austria }(21.3 \%) \\
\text { Sweden }(16.9 \%) \\
\end{array}$ \\
\hline $\begin{array}{l}\text { Wild collection } \\
\text { and further non- } \\
\text { agricultural } \\
\text { areas }\end{array}$ & $\begin{array}{l}\text { 2015: } 39.7 \text { million ha } \\
\text { (1999: } 4.1 \text { million ha) }\end{array}$ & $\begin{array}{l}\text { Finland (12.2 million ha) } \\
\text { Zambia (6.6 million ha) } \\
\text { India ( } 3.7 \text { million ha) }\end{array}$ \\
\hline Producers & $\begin{array}{l}\text { 2015: } 2.4 \text { million producers } \\
\text { (1999: } 200000 \text { producers) }\end{array}$ & $\begin{array}{l}\text { India (585 200) } \\
\text { Ethiopia (203 602) } \\
\text { Mexico (200 039) }\end{array}$ \\
\hline Organic market & $\begin{array}{l}\text { 2015: } 81.6 \text { billion US } \$ \\
\text { (approx. } 75 \text { billion } € \text { ) } \\
\text { (2000: } 17.9 \text { billion US } \$ \text { ) }\end{array}$ & $\begin{array}{c}\text { US } \\
\text { (39.7 billion US \$; } 35.8 \text { billion } € \text { ) } \\
\text { Germany } \\
\text { (9.5 billion US \$; } 8.6 \text { billion } €) \\
\text { France } \\
\text { (6.1 billion US \$; } 5.5 \text { billion } €)\end{array}$ \\
\hline $\begin{array}{l}\text { Per capita } \\
\text { consumption }\end{array}$ & $\begin{array}{l}\text { 2015: } 11.1 \text { US \$ } \\
\quad(10.3 €)\end{array}$ & $\begin{array}{c}\text { Switzerland (291 US \$; } 262 € \text { ) } \\
\text { Denmark (212 US \$; } 191 € \text { ) } \\
\text { Sweden (196 US \$; } 177 € \text { ) }\end{array}$ \\
\hline $\begin{array}{l}\text { Number of } \\
\text { countries with } \\
\text { organic } \\
\text { regulations } \\
\end{array}$ & 2016: 87 countries & \\
\hline $\begin{array}{c}\text { Number of } \\
\text { affiliates of } \\
\text { IFOAM- } \\
\text { Organics } \\
\text { International } \\
\end{array}$ & $\begin{array}{c}\text { 2016: } 833 \text { affiliates from } \\
121 \text { countries }\end{array}$ & $\begin{array}{c}\text { Germany - } 91 \text { affiliates } \\
\text { India - } 73 \text { affiliates } \\
\text { China }-55 \text { affiliates } \\
\text { United States - } 49 \text { affiliates }\end{array}$ \\
\hline
\end{tabular}

Source: Willer and Lernoud, 2017 
Figure 1. Global Organic Food Market Revenue Share, by Product

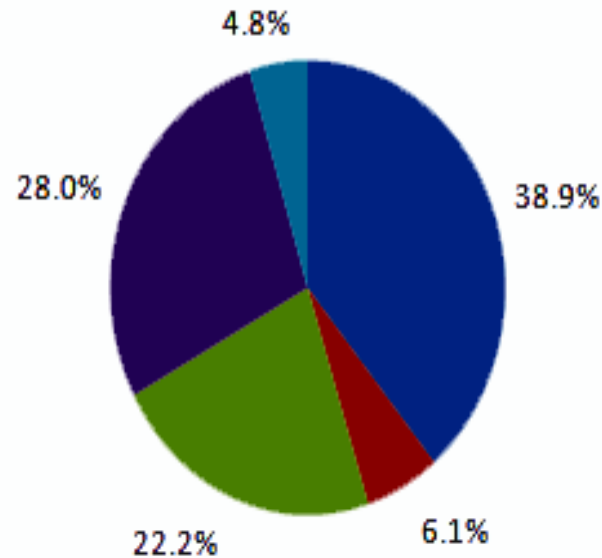

- Fruits \& Vegetables

Dairy Products neat, Fish \& Poultry Products

- Frozen \& Processed Food

Others

Source: http://www.grandviewresearch.com/industry-analysis/organic-foods-beverages-market

The demand for organic fruit is growing, both on the European and the world market. Fresh fruits rank first in the international trade (Batelja-Lodeta et al., 2012). The largest producers of organic fruits globally are Italy, Turkey, the USA, France, Spain, Poland and Germany. The US organic food market is characterized by a high proportion of organic fruits and vegetables (Figure 2), accounting for $40 \%$ of the entire organic food market (Willer et al., 2013). Worldwide, in 2006, there were close to 250,000 ha of continental species of organic fruit trees (pomes, drupes and berries). The price depends on fruit type and geographical location. Granatstein et al. (2008) state that leading manufacturers, such as Italy, Turkey, the United States, France, Spain, Poland and Germany, together make up three-quarters of the area under continental species of organic fruit trees on a global scale. 
Figure 2. U.S. organic food market revenue by product, 2014-2025 (USD Million)

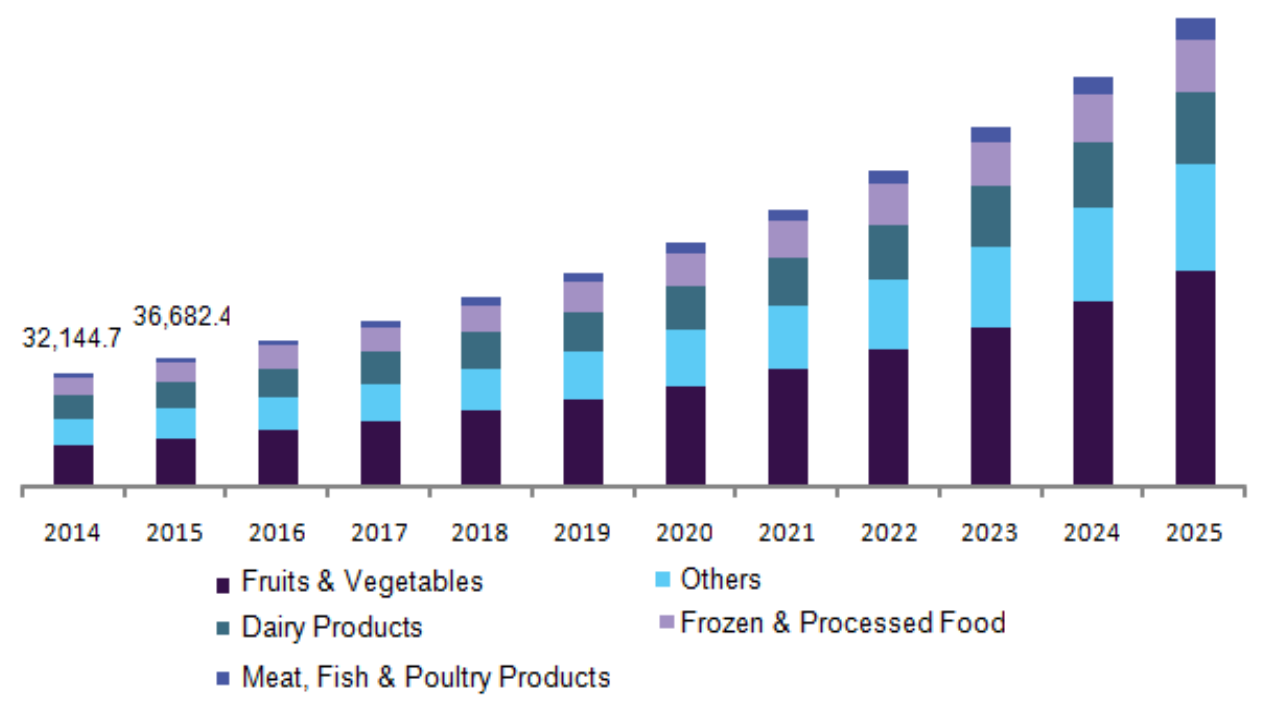

Source: http://www.grandviewresearch.com/industry-analysis/organic-foods-beverages-market

In 2015, globally, all countries recorded market growth for organic products, while in some countries the growth was double-digit. Thus, in 2015, the organic food market in Spain increased by 25\% (making the largest growth), Ireland 23\% and Sweden 20\% (Willer and Lernoud, 2017).

In 2015, in Europe, the organic food and beverage market has increased by $10 \%$, and the value was 31.1 billion $\$$. The German market doubled between 2004 and 2012 (Figure 3), and in 2015 it represents the largest organic food market in the amount of 9.5 billion US Dollars, followed by France, UK, Italy, Switzerland, Austria, Sweden, Denmark, Spain and the Netherland (organicworld.net).

The highest market share is in Denmark (organic foods comprise 8.4\% of the total food sales). Also, in 2012, the highest market shares were reached in Denmark (7.6 \%), followed by Austria (6.5 \%) and Switzerland (6.3 \%) (Figure 4). In Germany, which represents the largest country market, drugstores, supermarkets, discounters and organic food shops have developed private label ranges, and also, most chained outlets are in Germany, France and Italy (Willer and Lernoud, 2017). Germany was also the country with the largest organic food market in Europe in 2012, worth 7.04 billion euros, followed by France with EUR 4 billion (whose market has been very dynamic for the last few years), 
Great Britain (1.95 billion euros ), Italy (EUR 1.89 billion) (Figure 5) (Schaack et al., 2014).

Figure 3. Development of the organic market in selected European countries 2004-2012

\section{Development of the organic market in selected European countries 2004-2012}

Source: OrganicDataNetwork Survey 2014 based on national data sources and FiBL-AMI survey 2014

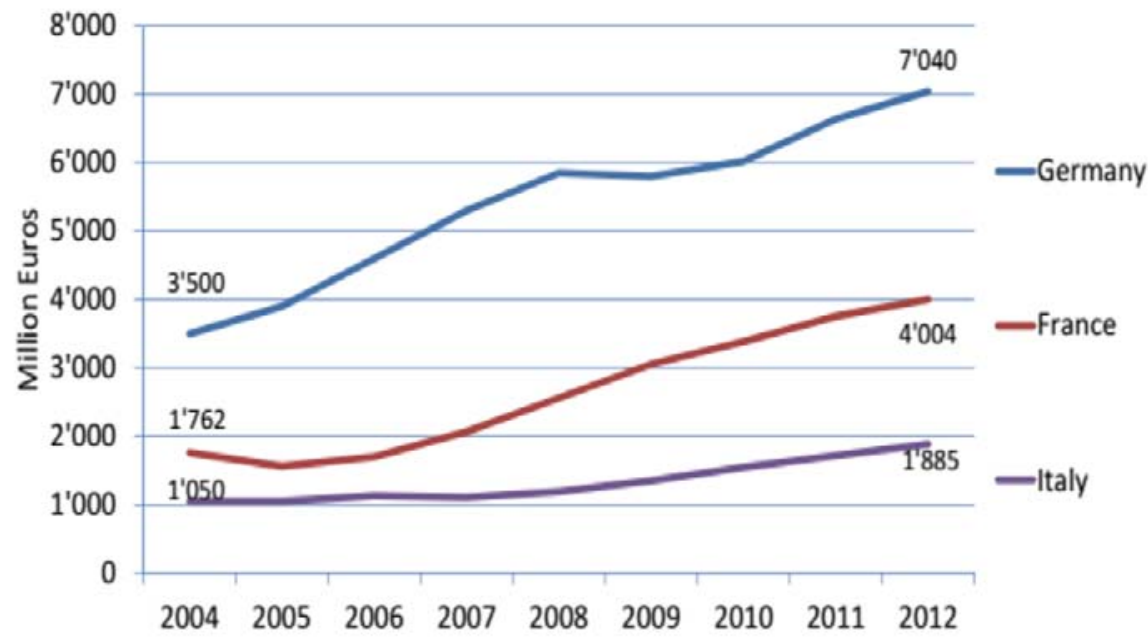

FiBL

\section{unw.fiblorg IFOAM}

Source: organic-world.net

In European countries, there is the highest per capita consumption, while in Switzerland there is not only the highest per capita consumption in Europe, but also in the world (189 euros in 2012, 262 euros in 2015), followed by Denmark with 191 euros in 2015 (which is a significant increase compared to 2012, when consumption was 159 euros) and Sweden with 177 euros (Schaack et al., 2014; Willer and Lernoud, 2017).

Royal Wessanen, one of the largest organic food enterprises, continues to acquire brands and it purchased Piramide Tea, Mrs Crimble's and IneoBio. It is one of the few companies with a pan-European presence, with a portfolio of brands that include Bjorg, Kallø Foods, Clipper, Allos, Isola Bio, Whole Earth, Tartex and Alter Eco.

The most chained outlets are located in Germany, France and Italy. In Germany and Austria, Dennree operates more than 200 Denn's Bio organic supermarkets, while in France, Biocoop chain has nearly 390 organic food shops, 
whilst there are over 300 Collobora B'io stores in Italy (Willer and Lernoud, 2017).

In the USA there is an increase in the share of traditional distribution channels, and a decrease in the share of organic food sales in health food stores and direct sales. According to Vaclavik (2009) in the European Union, the share of traditional organic food distribution channels has a tendency of dynamic increase, while the share of specialized and other distribution channels is decreasing. When it comes to Latin America, the largest organic product market is Brazil, which, due to the economic crisis, has been growing very slowly for many years, while the markets of Argentina, Peru, Chile and Colombia are mainly export-oriented.

Figure 4. Europe: The ten countries with the highest organic market shares 2012 (excluding catering)

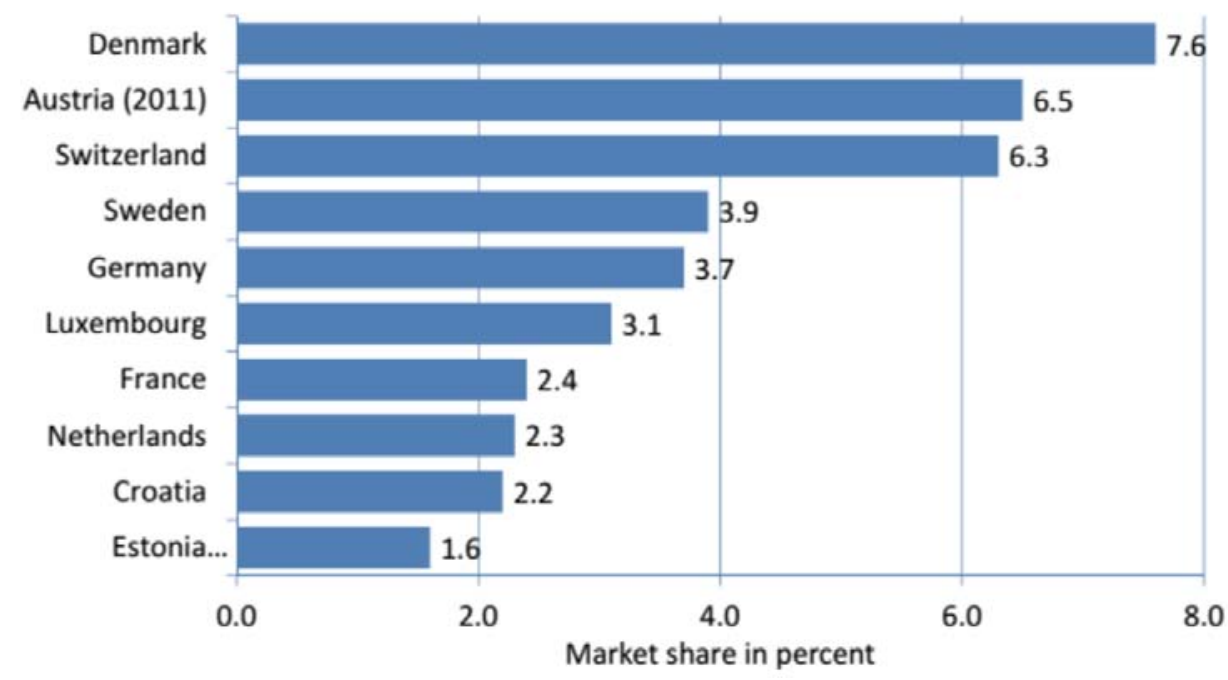

Source: Scaack et al., 2014. 
Figure 5. Europe: The ten countries with the largest markets for organic food and beverages 2012 (excluding catering)

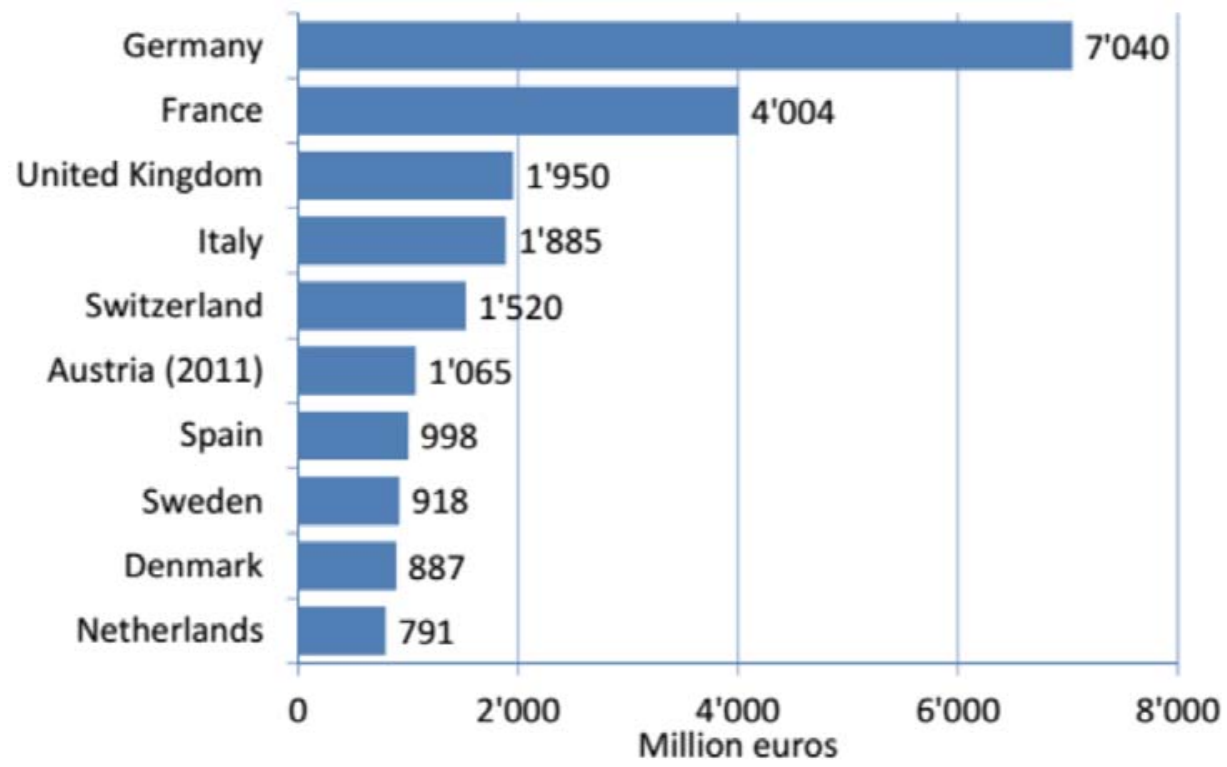

Source: Scaack et al., 2014.

In 2015, organic food sales in Australia, Asia and other regions amounted to about 7.2 trillion US dollars. When it comes to organic food sales, the Asian market continues to show a trend of growth, where China has a dominant role (extremely high production of oilseeds, herbs and related ingredients), followed by Japan, South Korea and Taiwan (FiBL, 2017). An extremely large market, which is growing steadily, is the Australian market, whose producers, together with New Zealand, are mainly export-oriented, especially to the countries of the Asian continent.

\section{Conclusion}

Organic farming has been growing in countries all over the world for many years. The purchase of organic foods is price-sensitive and depends on the personal income of consumers. Nevertheless, there is still a significant share of consumers in Serbia who are willing to pay 80 to $100 \%$ higher prices for the purchase of organic foods than the same products of conventional origin. Organic food sales in 2015 at global level had a value of 81.6 billion US \$, with the largest growth in the North American market, which accounts for more than half the value of international sales of these foods. In 2015, the growth of organic 
products market in all countries around the world was recorded, with the highest growth recorded in the Spanish market, which increased by $25 \%$.

\section{References}

Aguirre G.J.A. (2001): Marketing and consumption of organic products in Costa Rica. Working Paper, No. 5, The School for Field Studies, Centre for Sustainable Development, Atenas, Costa Rica.

Aertsens J., Mondelaers K., Verbeke W., Buysse J., Huylenbroeck G.V. (2011): The influence of subjective and objective knowledge on attitude, motivations and consumption of organic food. British Food Journal, 113 (11): 1353-1378.

Batelja Lodeta K., Gugić J., Čmelik Z. (2012): Ekološka poljoprivreda u Europi i Hrvatskoj s osvrtom na stanje u voćarstvu. Pomologia Croatica, 17 (3-4): 135-148.

Babović J. (2008): Agrobiznis u organskoj proizvodnji, Agromenadžment i standardi kvaliteta, Marketing organske proizvodnje, Multifunkcionalni i ruralni razvoj - agroturizam. Monografija, Organska poljoprivreda, Institut za ratarstvo i povrtarstvo, Novi Sad.

Brčić-Stipčević V., Petljak K. (2011): Research on organic food purchase in Croatia. Tržište: časopis za tržišnu teoriju i praksu, 23(2): 189-207.

Chinnici G., D'Amico M., Pecorino B. (2002): A multivariate statistical analysis on the consumers of organic products. British Food Journal, 104 (3/4/5): $187-$ 199.

Conner D. S. (2004): Consumer preferences for organic standards: does the final rule reflect them? Journal of Sustainable Agriculture, 23(3): 125-143.

Codron J.M., Siriex L., Reardon T. (2006): Social and environmental attributes of food products in an emerging mass market: Challenges of signaling and consumer perception, with European illustrations. Agriculture and human values, 23 (3): 283-297.

De Magistris T., Gracia A. (2008): The decision to buy organic food products in Southern Italy. British Food Journal, 110 (9): 929-947.

Ekelund L. (1990): Vegetable consumption and consumer attitudes towards organically grown vegetables - the case of Sweden. Acta Horticulturae, 259: 163-172.

FAO and WHO (1999): Joint FAO/WHO Food Standards Programme Codex Alimentarius Commission. Report of the 30th Session of the Codex Committee on Pesticide Residues, 2025 April 1998. The Hague faostat.fao.org Retrived: 5.7.2017.

FiBL (2017): http://www.fibl.org Retrived: 4.10.2017.

Golijan J.,Veličković M. (2015): Nutritivni sastav organski i konvencionalno proizvedenih namirnica. Hrana i ishrana, 56 (2): 43-46.

Golijan J, Popović A. (2016): Basic characteristics of the organic agriculture market. Proceedings of the Fifth International Conference Competitiveness 
Of Agro-Food And Environmental Economy, 10-11 November 2016, Bucharest: 236-244.

Golijan J. (2016): Motivi koji utiču na kupovinu organskih prehrambenih proizvoda. Agroekonomika, 45 (72): 73-80.

Golijan J., Kostić A.Ž., Pešić M.B., Stanojević S.P., Barać M.B., Lekić S. (2017a): Content of soluble sugars in cereals and soybean seeds grown under different conditions. $28^{\text {th }}$ International scientific-expert conference of agriculture and food industry, Sarajevo, Bosnia and Herzegovina, September 27-29, 2017, Book of abstracts: pp.103.

Golijan J., Kostić A., Lekić S. (2017b): Toxic metal health risk assessment in organic and conventional grown cereals/pseudocereals and soybean seed samples. $54^{\text {th }}$ Meeting Of The Serbian Chemical Society and $5^{\text {th }}$ Conference of Young Chemists Of Serbia, Belgrade, Serbia, September 29 and 30, 2017, Book of abstracts, pp. 102.

Golijan J., Kostić A., Dojčinović B., Lekić S. (2017c): The content of Ca, Mg and $\mathrm{P}$ in seeds of selected organic and conventional grown cereals/pseudocereals and soybean. $54^{\text {th }}$ Meeting Of The Serbian Chemical Society and $5^{\text {th }}$ Conference of Young Chemists Of Serbia, Belgrade, Serbia, September 29 and 30, 2017, Book of abstracts, pp. 55.

Granatstein D., Wiman M., Kirby E. and Mullinix K. (2008): Sustainability trade-offs in organic orchard floor management. Acta Horticulturae, 873: 115-122.

Hutchins R.K., Greenhalgh L.A. (1997): Organic confusion: sustaining competitive advantage. British Food Journal, 99 (9): 336-338.

http://www.grandviewresearch.com/industry-analysis/organic-foods-beveragesmarket Retrived: 1.9.2017..

Lazić B. (2010): Organska poljoprivreda - zalog za budućnost. Organic news, 1: 8-9.

Lernoud and Willer (Eds.) (2016): The world of organic agriculture. Statistics and Emerging Trends, 2016. Research Institute of Organic Agriculturae (FIBL), Frick, and IFOAM-Organic International, Bonn.

Makatouni A. (2002): What motivates consumers to buy organic food in the UK? British Food Journal, 104 (3/4/5): 354-352.

Marques Vieira L., Dutra De Barcellos M., Hoppe A., Bitencourt da Silva S. (2013): An analysis of value in an organic food supply chain. British Food Journal, 115(10): 1454-1472.

Miller G.T., Spoolman S. (2008): Environment Science: Problems: Concepts and Solutions, 12th ed., Stamford: Cengage Learning.

Organic-world.net Retrieved: 2.9.2017.

Padel S., Foster C. (2005): Exploring the gap between attitudes and behavior: understanding why consumers buy or do not buy organic food. British Food Journal, 107 (8): 606-625. 
Padel S., Midmore P. (2005): The development of the European market for organic products: insights from a Delphi study. British Food Journal, 107 (8): 626-646.

Popović A., Golijan J., Babić V., Kravić N., Sečanski M., Delić N. (2016): Organic farming as a factor for biodiversity conservation. International scientific conference on Ecological crisis: Technogenesis and climate change. April 21-23, 2016 Belgrade, Serbia, pp. 61.

Popović A., Golijan J., Sečanski M., Čamdžija Z. (2017): "Current status and prospects of organic production of cereals in the world". $6^{\text {th }}$ International Symposium on Agricultural Sciences AgroRes 2017, February 27-March 2, 2017 Banja Luka, Republic of Srpska, Bosnia and Herzegovina, Book of abstracts, pp. 102.

Pearson D., Henryks J., Sultan P., Anisimova T. (2013): Organic food: Exploring purchase frequency to explain consumer behavior. Journal of Organic Systems, 8 (2): 50-63.

Schaack D., Lernoud J., Schlatter B.,Willer H. (2014): The Organic Market in Europe 2012. http://orgprints.org/25254/1/schaack-et-al-2014-2014-03-05online.pdf Retrived: 5.10.2017.

Subić J., Bekić B., Jeločnik M. (2010): Značaj organske poljoprivrede u zaštiti okoline i savremenoj proizvodnji hrane. Škola biznisa, 3: 50-56.

Schifferstein H., Oude Ophuis P. (1998): Health-related determinants of organic food consumption in Netherlands. Food Quality and Preference, 9 (3): 119133.

Squires L., Jurić B., Cirnwell T. (2001): Level of market development and intensity of organic food consumption: cross-cultural study of Danish and New Zealand consumers. Journal of Consumer Marketing, 18 (5): 392-409.

Soil Association (2012): Organic Market Report 2012. Bristol (UK): Soil Association.

Tasić S. (2015): Implementacija agroekonomske politike EU na poljoprivredni i ruralni razvoj Srbije. Doktorska disertacija. Univerzitet Privredna Akademija u Novom Sadu, Fakultet za ekonomiju i inženjerski menadžment u Novom Sadu.

Thompson G.D. (1998): Consumer Demand for Organic Foods: What We Know and What We Need to Know. American Journal of Agricultural Economics, 80 (5): 1113-1118.

Torjusen H., Nyberg A., Wandel M. (1999): Organic food: consumers perceptions and dietary choices, SIFO-Report, No. 5-1999, National Institute for Consumer Research, Lysaker, Norway.

Vaclavik T. (2009): Specialised organic retail report Europe 2008.

Vehapi S. Z. (2014): Marketing strategija proizvođača organske hrane. Doktorska disertacija. Ekonomski fakultet, Univerzitet u Nišu, Niš, Srbija.

Vehapi S. (2015): Istraživanje motiva potrošača koji utiču na kupovinu organske hrane u Srbiji. Ekonomske teme, 53 (1): 105-121. 
Vlahović B., Tomić D., Popović V. (2010): “Stanje i perspektive potrošnje proizvoda organske poljoprivrede”, u: Forum o organskoj proizvodnji, (IV), Selenča,2010.

Von Alvensleben R. (1998): Ecological aspect of food demand: the case of organic food in Germany. AIR-CAT 4th Plenary Meeting: Health, Ecological and Safety Aspects in Food Choice, 4 (1): 68-79.

Willer H., Lernoud J. (Eds.) (2017): The World of Organic Agriculture. Statistics and Emerging Trends 2017. Research Institute of Organic Agriculture (FiBL), Frick, and IFOAM-Organics International, Bonn.

Willer H., Julia L., Beaute H., Amarjit S. (2013): "The World of Organic Agriculture-Statistics and Emerging Trends 2013". http://orgprints.org/26322/1/1606-organic-world-2013.pdf

Zander K., Hamm U., Freyer B., Goesssinger K., Naspetti S., Padel S., ... and Zanoli R. (2011): Consumer concerns regarding additional ethical attributes of organic food. Organic is Life: Knowledge for tomorrow, 2: 22-24. 


\title{
GLOBALNO TRŽIŠTE ORGANSKE HRANE
}

\author{
Jelena Golijan ${ }^{1}$, Bojan Dimitrijević ${ }^{1}$ \\ ${ }^{1}$ Poljoprivredni fakultet, Univerzitet u Beogradu, Beograd-Zemun, Srbija \\ Rezime
}

Organska poljoprivredna proizvodnja omogućava proizvodnju kontrolisane, sertifikovane, zdravstveno bezbedne, a pritom jako kvalitetne hrane, uz ostvarenje visokog ekonomskog i ekološkog profita i očuvanja zdrave životne sredine. Interes potrošača za proizvode organskog porekla permanentno raste već dvadeset godina. Cilj ovog rada je da dâ pregled stanja na globalnom tržištu organske hrane, kao i da ukaže na najvažnije motive zbog kojih se potrošači odlučuju za konzumaciju organski proizvedenih namirnica. Sve zemlje širom sveta beleže trend kontinuiranog rasta tržišta organske hrane i pića, dok je u nekim zemljama ovo povećanje dvocifreno. Sjedinjene Američke Države predstavljaju najveće tržište organske hrane, sa ukupno 35,8 milijardi evra. Vodeću ulogu na tržištu organske hrane u svim zemljama sveta imaju voće $i$ povrće, hleb, žitarice, piće, mleko i meso. U međunarodnoj trgovini, sveže voće zauzima prvu poziciju. Iako je proizvodnja i prodaja organske hrane koncentrisana u visoko razvijenim zemljama, i manje razvijene zemlje postaju značajni proizvođači i izvoznici organskih proizvoda, u prilog čemu ide činjenica da je izvozni potencijal na tržištu organske hrane neograničen.

Ključne reči: proizvodi, motivi, proizvođači, tržište. 